„Śląskie Studia Polonistyczne” 2019, nr 1 (13) ISSN 2353-0928 (wersja elektroniczna)

DOI 10.31261/SSP.2019.13.03

\section{Agata Araszkiewicz}

UMR LEGS CNRS/UPL PARIS 8/ PARIS NANTERRE

iD https://orcid.org/0000-0003-1769-2595

\section{Subwersja dziewictwa w filozofii Luce Irigaray}

W niniejszym tekście chciałabym prześledzić wywrotowość symbolicznej subwersji dotyczącej wątku dziewictwa w myśli francuskiej filozofki Luce Irigaray. By zrekonstruować potrzebne nam zaplecze refleksji, zacznijmy od tezy, że patriarchalny porządek społeczny, w którym ciągle funkcjonujemy, ufundowany jest na swoistym rozumieniu przejścia od natury do kultury zorganizowanym wokół zasady upodrzędnienia kobiet. Składa się na nią kilka elementów. Najważniejszy z nich to fakt, że to, co instynktowne i „zwierzęce”, a więc cielesne, relacyjne i bardziej pierwotne, musi zostać wyparte w edypalnej strukturze kultury i odesłane w sferę represji i stłumienia. W psychoanalizie Lacana porządek symboliczny, który możemy utożsamiać z porządkiem społecznym, zostaje zdefiniowany jako przejście od zależności i współobcowania z innymi, a nawet od miłości i namiętności do „walki i pracy” (IRIGARAY, 1977, s. 89). Uwidacznia się tutaj patriarchalna zasada rozdziału prawa i cielesności, a ceną za wyparcie preedypalnego erosa jest obietnica relacji heteroseksualnej i prokreacji. Patriarchalna heteroseksualność jest społeczną matrycą regulowaną przez fenomen męskiej dominacji w sensie symbolicznym, ekonomicznym i seksualnym wraz prawem, czy też przymusem, substytucji, czyli zastępowalności kobiet jako obiektów pożądania. W tym kontekście najważniejszą zasadą, porządkującą trwanie kultury patriarchalnej, jest opisana w Antropologii strukturalnej przez Claude'a LÉVI-STRAUSSA (1970) wymiana kobiet.

Według badacza, system pokrewieństwa nie opiera się na żadnych obiektywnych więzach krwi między jednostkami. Istnieje tylko w świadomości ludzi i jest arbitralnym sposobem przedstawiania, nie zaś spontanicznym rozwinięciem sytuacji faktycznej. Lévi-Strauss twierdzi kategorycznie: „w społeczeństwie ludzkim mężczyźni wymieniają kobiety między sobą, nie zaś kobiety mężczyzn" (LÉvi-Strauss, 1970, s. 107). Najprostszą, zdolną do pomyślenia strukturą pokrewieństwa jest - zdaniem filozofa struktura czteroczłonowa: brat, siostra, ojciec i syn, w której siostra jest obiektem wymiany w męskiej genealogii wedle ekonomiczno-rynkowego wzoru. Sprawne funkcjonowanie organizacji społecznej, fundujące nam ratunek przed „zwierzęcą” anarchią, 
zapewnia więc uczynienie z kobiet obiektów wymiany. Symbolicznym zabezpieczeniem takiego funkcjonowania struktury społecznej jest wartościowanie kobiet wedle ich strukturalnej pozycji w obrębie tej wymiany. Ten „cywilizacyjny” gest jest możliwy tylko przez wykluczenie podmiotowości kobiet i uczynienie z nich stawki zasady kontraktu społecznego między męskimi podmiotami. Irigaray podejmuje tezy Lévi-Straussa w swym tekście Rynek kobiet, w którym dowodzi, że porządek patriarchalny musi być ufundowany na zaprzeczeniu zasadzie określanej przez filozofkę jako czerwona krew, a więc wyeliminowaniu figury matki (które Irigaray określa jako matkobójstwo) oraz genealogii kobiecej. „Funkcjonowanie kultury, a przynajmniej kultury patriarchalnej” - pisze Irigaray - „oparte jest więc na zakazie powrotu do czerwonej krwi [rozumianej tu również jako związki cielesne - A.A.], w tym do seksu"' (IRIGARAY, 1977, s. 89). Struktura symboliczna i społeczna funkcjonuje więc na pierwotnym zawłaszczeniu pozytywnej dynamiki możliwej afirmacji kobiet, jak również na zrepresjonowaniu znaczeń, jakie reprezentują one w patriarchalnej wyobraźni. Najbardziej wyrazistym symbolem „urynkowienia” kobiet jest figura kobiety-dziewicy - dziewica na rynku ma czystą wartość wymienną. „Nie jest [ona - A.A.] niczym więcej jak miejscem, możliwością, znakiem relacji między mężczyznami" (Irigaray, 2003, s. 26)² - pisze filozofka.

\section{„Relacja seksualna nie istnieje”}

Myślenie Irigaray pokazuje, jak bardzo wszystko to, co może być określane „kobiecością”, podporządkowane jest formom i prawom męskiej aktywności. Po stronie natury mamy więc „zwierzęcość”, „seks”, preedypalność i kobiety bez przynależności. Po stronie kultury natomiast „cywilizację”, „zasady prokreacji”, edypalność oraz kobiety przynależne mężczyznom i podporządkowane regułom wymiany (choć zawsze pozostanie w kobietach coś z natury). Patriarchalna natura kontraktu społecznego polega więc na zapewnianiu mężczyznom dostępu do kobiet i ustanowieniu różnicy seksualnej jako podziału na sferę publiczną i prywatną, do której oddelegowane są kobiety, a także na useksualnionym podziale ich funkcji i pracy. Kontrakt symboliczny, podobnie jak kontrakt społeczny, jest także kontraktem seksualnym: zgodnie z jego zasadami, mężczyźni zyskują dostęp do kobiet (kobiety zostają wykluczone z transakcji symbolicznych między mężczyznami i stają się obiektami tych transakcji). Sama możliwość społeczno-kulturowej wymiany wymaga więc tylko tego, by wzięli w niej udział sami mężczyźni,

1 Jeżeli nie podano inaczej, cytaty w tłumaczeniu autorki artykułu.

2 Por. mój komentarz do tego tekstu (ArAszkiewicz, 2007, s. 136-145). W niniejszym artykule posiłkuję się w dużym stopniu rekonstytucją tez z tego artykułu. 
kobiety - jeśli chcą zachować pozycję podmiotów - mogą uczestniczyć w wymianie tylko jako „fałszywi” mężczyźni. Kobieta jest bowiem przede wszystkim stawką kontraktu społecznego, znakiem symbolicznych operacji (dotyczy to również wejścia kobiety w kulturę, język, prawo).

Porządek społeczny zakłada więc patriarchalną władzę przechodzącą z ojca na syna, męski monopol dostępu do wszystkiego, co znaczące, określany przez Irigaray jako „hom(m)oseksualnośc” (polega ona również na zakazie jawnych praktyk homoseksualnych jako zbyt subwersywnych). Oznacza takie uczestnictwo w systemie symbolicznym, w którym wszystko, co znaczące, pochodzi od mężczyzn i ogranicza się do męskiej metafory. „Hom(m)oseksualność” przede wszystkim czyni niewidzialną relację matka - córka, uwypuklając genealogię ojciec - syn, która wszędzie dowodzi swej symbolicznej skuteczności. Ustrukturowanie sfery popędowej w dynamikę „hom(m)oseksualną" powoduje, że normatywna heteroseksualność jest domeną wykluczania wszelkich alternatywnych form ekspresji tego, co cielesne, to zaś wiąże się z pragnieniem, pożądaniem, namiętnością i pasją. A właściwie z represją samej seksualności. Słynne stwierdzenie Lacana, że „nie ma relacji seksualnej”, oznacza w tym kontekście, że jedyne, co istnieje, to „fałszywie” braterska czysta relacja hom(m)oseksualna. Edypalny porządek społeczny bazuje na konieczności poświęcania i ograniczania w zamian za obietnicę (i nakaz!) heteroseksualnego dostępu do kobiet. W tym sensie kolejne słynne twierdzenie Lacana - „kobieta nie istnieje” - należy rozumieć przede wszystkim w sensie symbolicznym. Kobieta nie istnieje jako symboliczny podmiot. Ale dla Irigaray oznacza to właśnie, że obietnica relacji heteroseksualnej nie może zostać dotrzymana. To, co się tu odbywa, to zawłaszczona transakcja dominacji i kontroli seksualnej, dokonana na wypartym wzorze możliwej alternatywności innego - relacyjnego, wielopodmiotowego - spotkania. Przemieszczony wzór hegemonii seksualnej rozgrywa się wokół całkowitego wyparcia kobiety. Kobieta nie istnieje również dlatego, że nie może wziąć udziału w społeczno-symbolicznym kontrakcie. Pozostaje na zewnątrz niego i może do niego przystąpić jedynie ,jako mężczyzna" (WHITFORD, 1991, s. 177) (w tym sensie pozostaje także zawsze częściowo po stronie „natury”). „Jako kobieta” zostaje wykluczona z braterstwa i staje się jego cementującą podstawą - jest tylko obiektem męskiej przyjemności i wymiany.

Dziewictwo będzie w tym sensie formą możliwego wyodrębnienia podmiotowości kobiety, o ile podporządkujemy je innym, alternatywnym sposobom konceptualizowania afirmacji: samotności i samowystarczalności (nawet wobec relacji seksualnych z mężczyznami), ekonomii utraty (poza zasadą kumulacji i wymiany), odmowie zasady posłuszeństwa (przy zachowaniu otwartości i świado- 
mości samostanowienia). Dziewictwo to odpuszczenie potrzeby dominacji wobec swoistego continuum kobiecej zmysłowości, seksualności i potencjalnej macierzyńskości. To istnienie poza zasadą uprzedmiotowienia i hierarchii płci, ustanowione w miejsce wykluczenia. To obecność paradoksalna, której siła będzie polegała na subwersji symbolicznego porządku.

\section{Od gwałtu do dziewictwa}

Należy podkreślić, że patriarchalny wzór relacji heteroseksualnej cechuje się przede wszystkim zawłaszczeniem w sensie symbolicznym seksualności jako sfery cielesnej, popędowej i relacyjnej, jak również przekształceniem jej dynamiki w porządek stłumienia i męskiej kontroli. Zabezpieczenie zasady wymiany kobiet wymaga, by kontrola ta dokonywała przerwania kobiecej genealogii oraz zatopienia jej w męskiej. Córka zostaje oddzielona od matki, a następnie także od swojej rodziny, a następnie niejako przeniesiona do rodziny męża - nosi jego nazwisko, wychowuje „jego” dzieci. Separacja córki od matki (miłość między nimi ma być niemożliwa w patriarchalnym układzie, w którym co najwyżej mogą one być rywalkami) dokonuje się przez zastąpienie figury matki przez mężczyznę kochanka, który porywa córkę. Związek między córką i matką zostaje zmieniony na ,jej kult dla dzieci męża i samego męża jako męskiego dziecka" (IRIGARAY, 1991, s. 199).

Sytuacja ta najlepiej opisana została w micie o Demeter i Korze (ARAszKIEWICz, 2001). Jest on tutaj szczególnie istotny przede wszystkim dlatego, że uważa się go za pozostałość religii Matki i Córki. Analizy Karla KeréNYIEGo (2004) wskazują, że mniej więcej w latach 1400-1100 przed nasza erą istniała taka religia, a jej rytualną formę stanowiły misteria eleuzyńskie. W swych analizach Irigaray podkreśla, że bardziej istotny dla niej jest aspekt przerwanej genealogii i poddanie córki przemocowemu prawu Ojca (postać Kory) niż aspekt odradzającej się kobiecej siły i mimo wszystko silnej podstawy relacji między kobietami (Demeter). Hades porywa Korę (kore po grecku znaczy 'córka, dziewczyna') za zgodą Zeusa. Mężczyzna z ciemności, alter ego ojca, porywa córkę wbrew jej woli i wbrew woli jej matki w biały dzień całkowicie bezkarnie. Córki nie chroni już żadne prawo. Porwanie dokonuje się w świetle słońca, które występuje tu już jako symbol męskiej władzy - obowiązujące prawo czyni córkę widzialną i wydaną na przemoc, niezdolną do zachowania integralności ani do ukrycia się przed niebezpieczeństwem. Skazuje to młodą dziewczynę na rezygnację ze swoich praw, zmusza do szukania ratunku w podwójnym zaprzeczeniu - w cieniu i ukrywaniu się w ciszy. Domeną kobiecości staje się noc i nieświadomość. Demeter w swej rozpaczy nie zwraca się już do własnej matki - genealogia kobiet zostaje przerwana. 
Kultura patriarchalna, świat społeczny mężczyzn, system socjalizacji funkcjonują jak Hades (czyli mityczna grecka podziemna kraina śmierci) dla małej dziewczynki. W jej rozwijającej się heteroseksualności zawsze dominuje poczucie utraty siebie oraz wczesnego związku z matką. Mit pokazuje wyraźnie, jak bardzo heteroseksualny freudowski wzór kobiecej dojrzałości - polegający na uznaniu przez kobietę męskiej dominacji - skrywa to, że ufundowany został na gwałcie, przywłaszczeniu dziewictwa córki przez ojca, zakazie mówienia nałożonym na matkę i córkę. Od tej pory matkę będzie się przedstawiać jako zagrożenie niosące regres, skażenie, śmierć. Córka bez matki osunie się w niewidzialność, zapomnienie samej siebie, utratę tożsamości i duchową sterylizację.

Odebrane dziewictwo stanie się przedmiotem wymiany w rękach mężczyzn, choć dziewczynce wmówiono, że stanowi ono o jej integralności moralnej i psychicznej. Porwana Kora może na siebie patrzeć tylko przez pryzmat męskich wartości. Zachowa dziewictwo niby dla siebie, zapominając, że stanowi ono cenę na rynku rządzonym przez mężczyzn. Zachowa prawo do uwodzenia, ale tylko w funkcji męskich popędów. Mężczyzna porywacz staje się najważniejszą prefiguracją męskiej dominacji - kimś, kto pragnie uprawiać zdobywczą miłość cały czas, ale gdy walczy o przyjemność, unika reprodukcji. Zagroziłoby to męskiej władzy i potwierdziło moc macierzyńską. Matrofobia pozwala mężczyźnie zamaskować przerażający fakt: patriarchat jest ufundowany na gwałcie, kradzieży dziewictwa córki i użyciu go w sposób eksploatacyjny na poziomie wymiany dóbr, symbolicznej władzy, jak również na poziomie religijnym.

Córka, całkowicie poddana kontroli ojca, staje się jego kochanką. Wtrącenie dziewczynki w świat zinstytucjonalizowanych męskich popędów to przecięcie jej jedności duchowo-cielesnej, zaciemnienie tożsamości dziewczynki dla niej samej i dla innych kobiet, a także dla mężczyzn. To również oddzielenie jej ciała i rozkoszy od języka, miłości od pożądania (podmiotowości kobiet od męskich pragnień), oddzielenie porządku boskiego od praw ziemskiej rzeczywistości. Oznacza to ponadto, że „matka, instrument reprodukcyjny, naznaczony imieniem ojca i zamknięty w domu” - pisze Irigaray - ,jest własnością prywatną, wobec niej obowiązuje zakaz wymiany” (IRIGARAY, 2003, s. 26). Matka nie może krążyć jako obiekt wymiany, gdyż groziłoby to upadkiem porządku społecznego. W obu przypadkach i dziewica, i matka są pozbawione prawa do własnej rozkoszy.

Mit o Demeter i Korze świadczy też jednak o tym, że mała dziewczynka dochowuje tajemnicy swego związku z matką, wyraża bezgłośne pragnienie, aby słowo kobiecego dziewictwa było respektowane. To opowieść o przerwanej relacji matki i córki, ale obie pozostają jeszcze bohaterkami opowieści. Kora, nim porwie ją Hades, 
bawi się na łące wśród kwiatów, a scena ta podkreśla niewinność i seksualną czystość dziewczyny. Zmysłowość i próba ocalenia prawa do rozkoszy jest zapisana w tym obrazie. Heroiczna samotność Kory w jej przygodzie w pewnym sensie zwraca dziewczynie integralność, która w sensie symbolicznym podważa funkcję falliczną. Podobne znaczenie ma macierzyństwo Demeter, które jest rodzajem silnego olśnienia wobec możliwej utraty, osobistego przeżycia, które wzmacnia jej kobiecą moc. Ta para - matka i dziewica - uwyraźnia tutaj niewidzialną kobiecą genealogię, oddaje jej głos. W micie zasmuconą po stracie córki Demeter rozśmiesza Baubo - dziwna postać, której brzuch i łono tworzą twarz. Kobieca płeć Baubo jest równocześnie jej podmiotowością, zapisuje się na jej brzuchu. W greckich posążkach Baubo to właśnie brzuch dominuje jej wizerunek. Silne miejsce cielesności, seksualności i macierzyńskości jako miejsce połączenia matki i córki jest tutaj ciągle bardzo wyraźnie zaznaczone.

\section{Subwersja, czyli podwójny los dziewictwa}

Czy możliwy jest do pomyślenia inny niż istniejący obecnie system społeczny oraz symboliczny, a co za tym idzie, inny model ekonomii i języka? To najważniejsze pytanie filozofii Irigaray otwiera nas na inne rozumienie dziewictwa. W patriarchalnym rozdaniu dziewica, jako figura przemocowej koncepcji różnicy płci - jest tylko „miejscem, możliwością, znakiem relacji między mężczyznami” (IRIGARAY, 2003, s. 26). Zrytualizowane przejście od dziewicy do matki dokonuje się zaś przez „transgresję zasłony”, czyli przerwanie błony dziewiczej. Ten akt równocześnie usuwa kobietę z wymiany między mężczyznami i odsyła w strefę męskiej własności. Dla francuskiej filozofki najważniejsze zadanie do przemyślenia to przerwanie połączenia między dziewictwem a defloracją: to nie zerwanie dziewiczej błony określa, czym jest dziewictwo. Irigaray akcentuje znaczenie dziewictwa dla tożsamości kobiecej - dziewictwa jako ogólnoludzkiej wartości duchowej, konstytuującej podmiotowość i intersubiektywność, uwolnionej od zależności ekonomicznej i seksualnej od mężczyzny.

Dziewictwo jest tą częścią seksualności, która zostaje w kobiecie jako część jej integralności i nie może zostać przez nikogo zabrana. „Zachować dziewictwo” - pisze filozofka - „oznacza, że nie zatracimy się w pociągu do drugiej osoby, nie pozwolimy, by reguły innych całkowicie nami zawładnęły. [...] To oznacza, że możemy dać sobie kobiecy umysł i duszę, wewnętrzne schronienie, które nie jest tylko fizyczne, ale również duchowe: odsyła do oddechu, mowy, myśli" (IRIGARAY, 2004, s. 161). Język odsyłający do duchowości nie jest tu przypadkiem. Dla Irigaray patriarchat jako ufundowany na kradzieży i gwałcie dziewictwa córki, żeruje także na użyciu tego 
dziewictwa do handlu między mężczyznami, w tym handlu religijnego (IRIGARAY, 1989, s. 122). Reperacja tego nadużycia musi mieć nieuchronnie charakter duchowy, ponieważ dziewictwo reprezentuje kobiecą autonomię naraz cielesną i duchową. „Stawanie się dziewicą jest więc synonimem odzyskania przez kobiety aspektu duchowego" (IRIGARAY, 1987, s. 117). Autonomia dziewictwa, jak i renegocjacja relacji matka - córka, świadome stałe przepracowywanie treści wypartych do nieświadomości są dla filozofki nieodzownym krokiem, by kobiety mogły osiągnąć zintegrowaną tożsamość. To również poszerzy obszar ich cywilnej wolności. Próba tworzenia alternatywnych wizji społecznych nie może być oddzielona od duchowego wymiaru (nawet jeśli nie chodzi tu o restytucje żadnego współczesnego sacrum, wobec czego filozofka się dystansuje). Dla Irigaray wizja społeczeństwa, w którym kobiety mają poszerzone pole osobistej i duchowej jedności, to „bardziej sprawiedliwy porządek, który oznaczałby, że kobieta mogłaby być dziewicą albo matką dla siebie samej” (IRIGARAY, 1992, s. 136). I dalej: „te właściwości, tak ważne dla natury [kobiety - A.A.], fundowałyby jej duchowe stawanie się, jej prawa i powinności, zamiast ograniczać je jedynie do elementarnego naturalizmu, wedle którego dziewictwo równa się obecności hymenu, a macierzyństwo łączy się z faktem urodzenia dziecka" (IRIGARAY, 1992, s. 136).

Te podstawy zawarte w swoistej koncepcji dziewictwa jako projektu symbolicznego sprzyjałyby również stworzeniu innej przestrzeni współistnienia kobiet. By kobieta mogła wejść w inną formę organizacji społecznej, potrzebne jest inne rozumienie religii, inny język, inny model ekonomii, gdyż kobiety mogą wprowadzać inne wartości, odpowiadające kreacyjnym zdolnościom kobiet. Kobieca społeczność, społeczność między-kobietami, świat dla kobiet, który jak sięgamy pamięcią, nigdy nie istniał, jest jednocześnie obecny, możliwy, uśpiony i zrepresjonowany. Jest to świat innej miłości, innej ciągłości i kulturowej płodności między nimi. W myśleniu Irigaray ważne jest tutaj podkreślanie aktywizmu feministycznego. „Pierwszym krokiem przerwania ciszy dotyczącej eksploatacji doświadczanej przez kobiety - pisze filozofka, która bywa też aktywistką - jest systematyczna odmowa »bycia cicho«, realizowana przez ruch wyzwolenia kobiet" (IRIGARAY, 1977, s. 126). Dla kobiet najważniejszą sprawą jest kwestia ich „terytorialności” jako podmiotów, niezależnie od tego, czy ten, kto wchodzi w ich granice, jest zaproszonym gościem czy intruzem. $Z$ tego powodu nie tylko związana z macierzyństwem kwestia aborcji - jako prawa, by odmówić niechcianej obecności - lecz także na nowo rozumiane dziewictwo czyli prawo, by odmówić przekraczania naszych granic - są bazą praw cywilnych kobiet, warunkiem ich możliwego samostanowienia, bycia samych-dla-siebie (WHITFORD, 1991, s. 160). 
Myślenie Irigaray można w tym kontekście przeczytać jako swoisty nowy projekt „stawania się dziewicą”. Jego fizyczność zaznaczona jest silną cielesnością integralnej materialnej autonomii kobiecego ciała. Jego duchowość to swoista gama przepracowanych aluzji religijnych, które przewartościowują naszą uwagę skupioną na summum patriarchalnego przekazu paternalistycznej religii chrześcijańskiej, zawierającej się w figurze poświęconego mężczyzny reprezentującej porządek „w imię Ojca i Syna”. Genealogia męska zinkorporowała tu całkowicie genealogię kobiecą, upodrzędniając figurę kobiety jako matki jedynego „boskiego” dziecka syna. Macierzyński porządek czerwonej krwi zostaje tu całkowicie zamieniony w męskocentryczny obrzęd (zdanie „oto ciało moje i krew moja" powinno przecież odnosić się do kobiet). Przywrócenie postaci Kory, której dziewictwo jest nie tyle obiektem męskiego zawłaszczenia, ile wartością wzmacniającą relację dziewicy i matki (w miejsce poświęconego „boskiego” syna), odwraca porządek inkorporacji kobiecej genealogii przez męską. Ze wszystkimi tego konsekwencjami. Patriarchat zatapia kobiecą genealogię w męskiej, tworzy przemocową wersję różnicy płci, a równocześnie uniwersalizuje ludzkie podmioty pomimo różnicy. Rodzaj seksualny miesza się z rodzajem ludzkim, staje się „ludzką” rasą, która odzwierciedla tak naprawdę męską wspólnotę, odrzucającą - świadomie lub nie - możliwość innego rodzaju - kobiecego. W tak zdefiniowanym ludzkim rodzaju seks ma znaczenie tylko ze względu na reprodukcję lub jako domena realizacji męskich popędów. „Bycie” dziewicą zaś, zapisane tutaj jako forma do spełnienia czy do wytworzenia, to także odnowa kultury w sensie społecznym i duchowym. „Kobieta jest boska od narodzin, ale aby mogła pozostać boska, musi zachować swoją autonomię i dziewictwo, [...] strzec swej integralności przez zabezpieczenie swego własnego wnętrza" (IRIGARAY, 2004, s. 146-147) - pisze Irigaray.

Inny rodzaj wejścia kobiet w społeczną organizację i symbolikę jest możliwy, ale wtedy status kobiet musiałby się różnić od statusu mającego na celu realizację czystej funkcji reprodukcyjno-macierzyńskiej, która pozbawia kobiety podmiotowości. Struktura społeczna nie mogłaby polegać na uśmiercaniu kobiecych popędów, cojak dotąd - jest jej fundamentalną, bazową zasadą. Póki co większość istniejących form i norm społecznych jest ufundowana na oddzieleniu kobiet od siebie - kobiety od niej samej, ale także od innych kobiet. Odcięcie genealogii macierzyńskiej (mężczyzna pozostaje odcięty od kobiety/matki) powoduje, że odcięta jest także możliwość seksualnej relacji, a kobiety zmuszone są do zastąpienia miejsca matki i agresywnej z nią rywalizacji. „A co z relacją dziewczynki i jej własnej matki?” - pisze Margaret Whitford, badaczka filozofii Irigaray „Irigaray proponuje po macierzyńskiej stronie inną ekono- 
mię [...], uzależnioną od ciągłości związków, ekonomię, w której płodność zajęłaby miejsce poświęcenia" (WHITFORD, 1991, s. 181). Miłość, namiętność, płodność to więc zrepresjonowane wartości, które edypalny patriarchat zastępuje walką, pracą i poświęceniem. Aby je odrestaurować, potrzebna jest inna symbolizacja relacji matka córka; w relacji tej córka nie musiałaby być zamiast matki, ale mogłaby być z nią. Inna kobieca podmiotowość to cielesność i inna seksualność niebędące tabu. Inne upłciowienie podmiotowości $\mathrm{i}$ inne rozumienie reprodukcji. I wreszcie - co najważniejsze - inne rozumienie dziewictwa: jako subwersji, nieposłuszeństwa, odmowy uznania rynku kobiet i otwartego projektu nowej kobiecej, zintegrowanej fizycznie i duchowo podmiotowości.

Figura dziewicy jest tutaj istotna, ponieważ daje możliwość podwójnej lektury, ale także przepracowania tego rozdwojenia. W filozofii Irigaray często pojawia się wątek kobiety, będącej jednocześnie wewnątrz i na zewnątrz tego, co symboliczne, doznającej siebie w wiecznym konflikcie, który jest efektem alienacji, związanym z wykluczeniem kobiety, czy opuszczeniem jej przez symbolikę, określanym jako déréliction. Ale jej „relikty” zawsze gdzieś pozostają, więc owo doznanie fragmentaryczne, niespójne, niepoddające się jednorodnej wykładni, poczucie bycia jednocześnie tu i gdzie indziej jest po prostu odzwierciedleniem symbolicznej pozycji kobiety. „Czy pod pretekstem wyzwolenia - pyta Irigaray - nie dezerteruje ona podwójnie od siebie samej: nie odkrywa siebie jako takiej, jako scalonej, opuszczając siebie, by się szukać tam, gdzie jej nie ma?” I dalej komentuje: „Wymazuje ślady kobiecości już zakopane albo tak sekretne, że nawet nie są one widzialne" (IRIGARAY, 1996, s. 10-11).

Kora jest właśnie owym śladem, tropem do przemyślenia i przyswojenia na nowo. Jej samotnośći pragnienie powrotu do matki ukazują w duchowym wymiarze ukłon Kory w stronę cielesnych więzi i szacunek dla nich. Uprzywilejowuje to współzależność i relacyjność. Kory pragnienie innej cielesności, innych relacji z mężczyznami przede wszystkim wyraża uparte trwanie przy relacjach z kobietami. Kora jako „inna” dziewica to wykluczona figura kobiecej genealogii, która odsyła mężczyznę, męski, patriarchalny, „ludzki” podmiot do szacunku dla matki i kobiety. I wreszcie „stawanie się dziewicą" to projekt integralnej, odzyskanej kobiecej podmiotowości: kobiety dla niej samej, w jej skomplikowanym samodoznaniu, samospełnieniu i samopobudzeniu. Nieodciętej od swej popędowości ani podmiotowości, niedefiniowanej wedle rangi wartościowania na rynku kobiet, integralnej, dziewiczej i płodnej. Ale także kobiety wśród kobiet, wyłaniającej się z kobiecej genealogii, czerpiącej rozkosz z relacji z kobietami, sprawczej w świecie społecznym (i z mężczyznami) i przekształcającej jego struktury. To powrót do czegoś 
utraconego, co może być bazą na nowo przemyślanej wolności i autonomii kobiet. To wreszcie intensywny postulat odwracania znaczeń kultury patriarchalnej, próba odzyskania dostępu do namiętności i ufundowanego na niej myślenia, które, rewidując początek, zmieniają rozumienie świata, w którym funkcjonujemy.

Para dziewica i matka - dziewica, która staje się kobietą na swoich prawach, i matka, która pozostaje w pewnym sensie nową, ,inną” dziewicą - interpeluje nie tylko religijny patriarchalny mit kobiety odciętej od swego ciała będącego na usługach uprzywilejowanej symbolicznie męskiej genealogii. Dziewictwo i ciąża (IRIGARAY, 2004, s. 197) (czyli symbol bycia matką i macierzyńskości, a także reprodukcji), jak podkreśla Irigaray, konstytuują podstawę myślenia o prawach kobiet dzisiaj, akcentując nie tylko to, co wolno nam mieć, ale przede wszystkim to, jakie możemy być.

\section{Samopobudzenie:}

\section{różnica seksualna kontra etyka różnicy płci}

Zatrzymajmy się na chwilę przy jednej z najciekawszych kategorii myślenia irigariańskiego, opisanej przez Katarzynę Szopę, czyli samopobudzeniu (SzoPA, 2018, s. 206-214), kategorii, która staje się jeszcze bardziej czytelna w kontekście projektu innego rozumienia dziewictwa. Samopobudzenie odnosi się najściślej do „energii relacyjnej, rozumianej jako skłanianie się ku innemu" (SzopA, 2018, s. 206) i wiąże się z przezwyciężaniem dualizmów i hierarchii podmiotowości. Matryca owej relacyjności leży w pierwotnym związku z matką, który filozofka stale przedefiniowuje, analizując modele rozwoju przypisane dla obu płci. Dziewczynka konstruuje swoje pragnienie bycia-z-innym(i), czyli swoją relacyjność, opierając się przede wszystkim na fakcie, że pierwszy obiekt pożądania tej dziewczynki ma tę samą płeć. W tym sensie między dziewczynką-córką a matką istnieje pewna forma pierwotnej więzi homoseksualnej, która musi zostać wyparta przez heteroseksualny porządek. Proces ten wytwarza również ów efekt poczucia nieprzystosowania i fragmentaryczności (oraz latentną pozycję homoseksualną, gdyż heteroseksualność jest tu zawsze niedomknięta). Mężczyzna zaś, wchodząc w porządek „w imię Ojca”, przyjmuje łatwiej kulturę matkobójstwa i związany z nią przymus substytucji - zastępuje matkę innymi kobietami, znajdując się w całkowitej konfuzji wobec ich podmiotowości. Owa nieprzepracowana relacja z początkiem wytwarza heteroseksualny porządek nadużycia: kobieta w pewnym sensie nie może wyrwać się z obszaru męskich fantazmatów i ustanowić swojego integralnego kulturowego, symbolicznego statusu, a mężczyzna musi utracić zdolność współ-bycia i współ-dzielenia się w relacji. Bliskość i intymność muszą zostać zastąpione kategoriami własności (przy- 
właszczania) i wymiany. Występująca więc jednocześnie obecność i obcość kobiet jest rodzajem niedoreprezentowania symbolicznego, które należy przepracować, ustanawiając z otchłani męskich fantazmatów własny wzór bycia. Mężczyzna zaś, aby przekroczyć przymus substytucji, musi odzyskać kontakt z życiem, dotąd zdominowany przez zwrócenie się do śmierci, i przepracować (w stronę szacunku i afirmacji) swój stosunek do inności i obcości.

Kategoria samopobudzenia (self-affection) w wypadku kobiet oznacza więc rodzaj „powrotu do siebie” na nowych zasadach. To zdolność do zachowania własnej przestrzeni integralności wewnętrznej, zdolność do poczucia wewnętrznego kontaktu i „relacji bycia w sobie i z sobą, słowem: bycia (z) sobą” (SzopA, 2018, s. 210). Samopobudzenie więc, jako przede wszystkim umiejętność pozostawania sobą, odbywa się w intymnym wymiarze podmiotowości, ale równocześnie jest siłą, która wytwarza warunki otwarcia się na inność. W greckim micie Kora, nieświadoma niczego, zrywa kwiat narcyza i wtedy rozstępuje się ziemia, a z niej wyłania się Hades, który dokonuje porwania. Irigaray naciska na nie-narcystyczne znaczenie działania samopobudzenia, które nie może być ani autystycznym skupieniem się na immanencji, ani egocentryczną ekspansją kastrującą innych. Gdyby odwrócić scenę porwania i przepracować inne wzory kształtowania się podmiotowości, to być może nasza wewnętrzna praca, jako praca kobiet z tematem narcyzmu, mogłaby prowadzić nas w stronę innego autodoznania i doznania świata. Świata, który nie traktowałby naszego rozwoju z przemocą i ograniczeniami oraz wpisaniem w reguły pozbawiające nas prawa do samostanowienia. Chodzi o autodoznanie wzmacniające nasze poczucie sprawczości i mocy tworzenia relacji z innymi, także z mężczyznami, którzy nie musieliby odpowiadać przemocą i uprzedmiotowieniem w sytuacji odzyskania prawa do bliskości i intymności, polegającego na uprzywilejowaniu poczucia wspólnoty i współ-odpowiedzialności. Dziewictwo mogłoby wtedy zaistnieć jako kategoria, która może zostać rozwinięta przez samopobudzenie, ono zaś przez Irigaray jest rozumiane jako dyspozycja zarówno cielesna, jak i duchowa, jako kategoria ściśle związana z energią relacyjną, dzięki której podmiot może wchodzić w relacje z innymi ani nie zatracając (nie zawłaszczając) ich wolności, ani jej nie tracąc, czy nie przeżywać lęku o wieczne jej zagrożenie.

Co za tym idzie, koncepcja niesymetrycznej różnicy seksualnej, która hierarchizuje płcie i legalizuje zawłaszczenie tego, co kobiece, przez męskość, rozumianą jako hegemonia symboliczna, uległaby modyfikacji w postulowaną stale przez Irigaray etykę różnicy płciowej. Sama koncepcja różnicy płciowej odnosi się w myśli filozofki do tego, czym istniejące rozumienie różnicy seksualnej nie jest. Różnica płciowa oznacza pewne otwarte miejsce do wypowiadania, usytuo- 
wane poza kategoriami identyczności czy opozycji, miejsce wykluczone przez dyskurs, w którym być może wystąpiłoby ono jako niespójne kulturowo czy niemożliwe do pomyślenia (SzoPA, 2018, s. 176) (narzędzia, żeby to miejsce wytworzyć, musimy ciągle wypracowywać). Dla Irigaray istotna jest tu płciowość jako materialność, różnica upłciowiona (a nie useksualniona), która otwierać się może na wszelkie dotąd niedoreprezentowane, choć uwzględnione potencjalności, przede wszystkim na te, które zostały wykluczone. Koncepcja różnicy płciowej wypracowuje się poprzez etyczne rozważania o fakcie istnienia człowieka w relacyjności, w relacjach z innymi i samym sobą, dla innych i również dzięki nim. W tym sensie każde zetknięcie z innym wydarza się przez poznanie jego odmienności i autonomii w nieredukowalnej przestrzeni bliskości, owego „pomiędzy”, które wydarza się w spotkaniu. Dla Irigaray różnica płciowa jest projektem, który z definicji obejmuje to, co alternatywne, przepracowane i fantazmatyczne, sytuuje się po stronie nieskończoności niestabilnych i otwartych procesów wchodzenia w relacje, poddanych nieustannej mocy wydarzania się nieprzerwanie. Ostatecznie oznacza to totalną renegocjację zastanych "trybów produkcji podmiotowości, opartych na normatywnych ramach" (SzopA, 2018, s. 189) i otworzenie oraz współ-tworzenie kultury przez występowanie wszelkich, dających się wypracować, pomyśleć i zamanifestować, różnic.

Na nowo przemyślane dziewictwo oraz związane z nim samopobudzenie, które jako zróżnicowane „heteropobudzenie” jest doświadczeniem ujmującym różnorodność wewnątrzrelacyjną, konstruującą się poza podziałem na stronę bierną i czynną czy poza relacjami podmiotowo-przedmiotowymi (które „heteropobudzenie" wypierają) - to podstawy pomyślenia i praktykowania etyki różnicy płciowej, otwartej na proces, innowację, zaskoczenie i afirmację w nieredukowalnych różnicach.

\section{Bibliografia}

Araszkiewicz Agata, 2001: Poza zakazem kazirodztwa. W: Lektury inności. Antologia. Red. Mieczysław DĄBRowski, Robert PRUszczyński. Warszawa: Wydawnictwo Elipsa.

Araszkiewicz Agata, 2007: Czarny ląd czarnego kontynentu. Relacja matka - córka w ujęciu Luce Irigaray. W: Ciało, płeć, literatura. Prace ofiarowane Profesorowi Germanowi Ritzowi w pięćdziesiąta rocznice urodzin. [Red. Magdalena Hornung, Marcin JĘDRzejczaK, Tadeusz KorSAK]. Warszawa: Wiedza Powszechna.

IRIGARAY Luce, 1977: Ce sexe qui n'en est pas un. Paris: Editions de Minuit. IRIGARAY Luce, 1987: Sexes et parentés. Paris: Editions de Minuit. 
IRIGARAY Luce, 1989: Le Temps de la différence. Pour une révolution pacifique. Paris: Libraire Générale française, Livre de poche.

IRIGARAY Luce, 1991: The Necessity for Sexuate Rights. In: The Irigaray Reader. Ed. Margaret WHitford. Oxford-Cambridge: Blackwell Publishers.

IRIGARAY Luce, 1992: J'aime à toi. Esquisse d'une félicité dans l'Histoire. Paris: Grasset.

IRIGARAY Luce, 1996: Introduction. In: Le souffle des femmes. Luce Irigaray présente des credos au féminine. Ed. Luce IRIGARAY. Paris: Action Cathol.Gen.Femine.

Irigaray Luce, 2003: Rynek kobiet. Przeł. Agata Araszkiewicz. „Przegląd Filozoficzno-Literacki”, nr 1 (3).

IRIGARAY Luce, 2004: The Redemption of Women. In: EADEM: Key Writings. Ed. Luce IrIgaRAY. London-New York: Continuum.

KERÉNYI Karl, 2004: Eleusis. Archetypowy obraz matki i córki. Przeł. Ireneusz Kania. Kraków: Homini.

LÉvi-STRAuss Claude, 1970: Antropologia strukturalna. Wstępem poprzedził Bogdan Suchodolski. Przeł. oraz Słownik Pojęć Antropologii Strukturalnej oprac. Krzysztof Pomian. Warszawa: Państwowy Instytut Wydawniczy.

Szopa Katarzyna, 2018: Poetyka rozkwitania. Różnica płciowa w filozofii Luce Irigaray. Warszawa: Instytut Badań Literackich PAN. Wydawnictwo.

WhITFORD Margaret, 1991: Luce Irigaray: Philosophy in the Feminine. London-New York: Routledge.

Agata Araszkiewicz

\section{Subversion of Virginity in Luce Irigaray's Philosophy}

Summary: Symbolically subversive facet of the virginity motif in Luce Irigaray's philosophy is the major focus of the presented text. It commences by citing a thesis by Claude Lévi-Strauss speaking of the patriarchal social structure, which exercises heteronormative sexuality and reproduction control, being based upon the principle of the exchange of women. What the said subjugation of women and turning them into means of exchange by masculine subjects entails, is repression of feminine subjectivity, corporeality, sexuality, masculine dominance becoming paramount, and the coercion of heterosexual male substitution, that is, transformation of women into replaceable entities. Irigaray calls this phenomenon "the women market" - the principle of patriarchal culture which establishes their prices based on their structural position in circulation. The virgin - an obvious sign of transaction taking place between men - is utilized by Irigaray as a basis for a new project of female autonomy which, in turn, instigates entirely new order of the corporeal, drives and desires, designed for symmetricity, 
closeness, and relationality. Juxtaposing this project with a category of "self-excitability," which sees feminine subjectivity as immanently causative, lead us to a redefinition of the traditional pattern of sexuate/sexual difference founded on hierarchy and repression, aimed at the ethics of sexual/sexuate difference and their inclusive openness to newly-defined, variegated, and manifold subjectivities.

Keywords: virginity, virgin, the exchange of women, the women market, female subjectivity, sexual/sexuate difference, ethics of sex/sexual/sexuate/gender difference, self-excitation, Luce Irigaray, Demeter and Kore

\section{Agata Araszkiewicz}

\section{La subvertion de la virginité dans la philosophie de Luce Irigaray}

Résumé : Le texte se concentre sur la valeur révolutionnaire de la subvertion relative au motif de la virginité dans la pensée de la philosophe française Luce Irigaray. Le point de départ pour l'auteure de l'article est une thèse de Claude Lévi-Strauss que la structure patriarcale de la société consistant à contrôler hétéronormativement la sexualité et la reproduction est fondée sur le principe d'échange des femmes. La soumission féminine et l'échange des femmes par les sujets masculins sont liés à la répression de la subjectivité, de la corporéité et de la sexualité féminines, la suprématie du principe de la domination masculine et la contrainte de la substitution masculine hétérosexuelle c'est-à-dire de la substituabilité des femmes. Irigaray appelle ce phénomène « le marché des femmes » - le principe de la culture patriarcale qui estime les femmes en fonction de leur position structurelle dans la circulation. La vierge - le signe pure de la transaction entre les hommes - devient pour Irigaray prétexte pour créer un nouveau projet de l'autonomie féminine qui occasionne un autre ordre du corps, des instincts et des désirs visant la symétrie, la proximité et la relation. Le rapprochement de ce projet de la catégorie de « l'autoagitation » qui permet de comprendre la subjectivité féminine en tant que constamment causative nous mène à une redéfinition du modèle traditionnel de la différence sexuelle basé sur la hiérarchie et la répression vers l'éthique de la différence sexuelle et son ouverture inclusive aux subjectivités définies de nouveau, différenciées et multiples. Mots clés : virginité, vierge, échange des femmes, marché des femmes, subjectivité féminine, différence sexuelle, éthique de la différence sexuelle, auto-excitation, Déméter et Coré 